\title{
Coastal and Inland Weather Contrasts in the Canadian Arctic ${ }^{1}$
}

\author{
C. I. JACKsON ${ }^{2}$ \\ Department of Geography \\ McGill Universily, Montreal, Quebec
}

\begin{abstract}
A record of surface weather was maintained at the Canadian IGY base at Lake Hazen, Ellesmere Island, from August 1957 to August 1958. This is the first such record from the interior of any of the Canadian Arctic Islands and shows great differences from the permanent stations on the coasts. Winter temperatures were very much colder, and winds were very light, even during severe gales elsewhere. It is suggested that a continuing record from this or a similar location would be of great value, particularly if upper air soundinge were also made.
\end{abstract}

The establishment of five permanent Canadian-United States weather stations in the Queen Elizabeth Islands of the Canadian Arctic has been of great value for high-latitude synoptic analysis. The stations are also providing continuous surface data and, finally, have been used as bases for general scientific studies in their vicinities.

None of the stations, however, were sited away from tidewater, and the surface records are essentially those of arctic maritime stations. On Ellesmere Island, for example, Eureka is located on an arm of Eureka Sound, 8 feet above sea-level on the west coast. Alert, on the north coast, is about a mile inland and 218 feet above sea level. All the earlier expeditions which made major contributions to the scientific discovery of the island-the British Admiralty Expedition of 1875-1876 under Nares [Great Britain, Parliamentary Papers, 1877], the American First Polar Year Expedition 18811883 led by Greely [1888], and Sverdrup's Second Fram Expedition 1898-1902 [Mohn 1907-1919]-were based at different points on the coast, and references to the weather experienced inland are generally few. The record of surface weather maintained at the Canadian IGY Expedition Base Camp at Lake Hazen

\footnotetext{
1 Sponsored by the Defence Research Board of Canada and based on a paper presented to a joint meeting of the Union and the American Meteorological Society, Washington, D. C., May 4-7 1959.

2 Present address: 172, Forest Lane, Harrogate, Yorkshire, England.
}

from August 20, 1957, to August 10, 1958, is the first record from an inland station on any of the Canadian Arctic Islands for so long a period.

The Lake Hazen station was approximately 100 miles southwest of Alert and 220 miles northeast of Eureka, at $81^{\circ} 49^{\prime} \mathrm{N}, 71^{\circ} 18^{\prime} \mathrm{W}$, and 528 feet above sea level. The lake itself, which is about 45 miles long, $71 / 2$ miles wide, and very deep, lies in a trough trending approximately northeast-southwest. On the northwest side of the lake, rising behind the Base Camp, is the Garfield Range, with peaks at about 3300 feet; on the southeast side is the much lower GreelyHazen plateau. This is ice-free, whereas behind the Garfield Range lies a considerable icefield. Navigable tidewater extends to about 20 miles from the lake at the head of Chandler Fiord, but the station is far enough from the open sea to have a distinctly 'inland' climate.

Three-hourly observations were maintained throughout the period according to the practices of the Canadian Meteorological Service, and a microfilm copy of the records is deposited at its head office in Toronto. An extensive discussion of the records is being prepared by the author.

Of the various climatic parameters measured or observed at Lake Hazen undoubtedly the most significant were temperature and wind. It is these which provide the greatest contrasts with Alert and Eureka on the coasts and which, separately and in combination, are of most significance for human habitation in the Lake Hazen area.

The first few years of records from the Joint 
TABLE 1-Frequencies of temperatures below various limits

Alert and Lake Hazen: August 21, 1957, to Auguat 10, 1958; Eureka: September 1, 1957, to August 10, 1958.

\begin{tabular}{|c|c|c|c|c|c|c|}
\hline \multirow[b]{2}{*}{ Limits } & \multicolumn{2}{|c|}{ Lake Hazen } & \multicolumn{2}{|c|}{ Eureka } & \multicolumn{2}{|r|}{ Alert } \\
\hline & $\begin{array}{c}\text { Days in } \\
\text { limits }\end{array}$ & $\begin{array}{l}\text { In and below } \\
\text { limits }\end{array}$ & $\begin{array}{c}\text { Days in } \\
\text { limits }\end{array}$ & $\begin{array}{c}\text { In and below } \\
\text { limits }\end{array}$ & $\begin{array}{l}\text { Days in } \\
\text { limits }\end{array}$ & $\begin{array}{l}\text { In and below } \\
\text { limits }\end{array}$ \\
\hline Below freezing & 294 & & 289 & & 320 & \\
\hline 0 to $-20^{\circ} \mathrm{F}$ & 38 & 225 & 33 & 204 & 62 & 206 \\
\hline-20 to -40 & 66 & 187 & 88 & 171 & 115 & 144 \\
\hline-40 to -50 & 48 & 121 & 57 & 83 & 28 & 29 \\
\hline-50 to -60 & 63 & 73 & 24 & 26 & 1 & 1 \\
\hline Below -60 & 10 & 10 & 2 & 2 & 0 & $\mathbf{0}$ \\
\hline
\end{tabular}

Weather Stations have indicated that the cold pole of North America is in the vicinity of Ellesmere Island and not in the Barren Grounds of the continental mainland. Table 1 shows that very cold temperatures during the long winter are even more common inland than the coastal stations would suggest. The temperature reached $-50^{\circ} \mathrm{F}$ on only 1 day at Alert during the winter of 1957-1958, but on 73 days at Lake Hazen, whereas temperatures of $-40^{\circ} \mathrm{F}$ or below were recorded at the inland station on exactly one-third of the days in the year. The period of observations included the month of January 1958, which was remarkable for the high temperatures in the Canadian Arctic [Thomas and Titus 1958]. Freezing rain and above-freezing temperatures were recorded at Alert, and there can be no doubt that the number of days with very low temperatures would be considerably greater in a more normal winter. As the summers are generally cool (the maximum temperature at Lake Hazen in 1958 was only 59.2 ; in 1957 , as recorded by an advance party, it was 62 ), the mean annual temperature in $1957-1958$ of about $-6^{\circ} \mathrm{F}$ makes it one of the coldest ice-free areas on earth.

To some extent these low temperatures are a result of the location of the inland station. Situated close to the foot of a mountain range, with an icefield behind, Lake Hazen is at the bottom of a gigantic frost hollow. But more important than the nearness of the mountains is the lack of moderate or strong winds which normally do much to 'roll up' an inversion by mechanical turbulence. The record of wind at Lake Hazen shows a remarkable number of calms and light winds, and presents even more of a contrast with the coasts than the temperature records. The lack of wind, it must be stressed, was not due to the poor exposure of the anemometer. The presence of the mountains in the quadrant between west and north might lead one to expect underrepresentation from that direction, but otherwise the winds have a practically uninterrupted flow along or across the lake. Yet 58 per cent of the more than 2800 three-hourly observations recorded either calms or winds of $1 \mathrm{mph}$. The months of November and December 1957 and February and March 1958 had an average of 66 per cent of calms, and winds above $20 \mathrm{mph}$ were recorded only in August 1957 and January and July 1958. Winds of 20 $\mathrm{mph}$ or more occurred at 243 synoptic observations during the same period at Eureka and on 309 occasions at Alert, representing 11 per cent of all observations. The total number of occasions at Lake Hazen was only 29, and 17 of these were in late August 1957. On several occasions winds of $70 \mathrm{mph}$ or more were recorded at Alert and Eureka, whereas Lake Hazen, between them, recorded little or no air movement. Even during the exceptional gale of January 1958, seventy-five years to the day after Greely's similar experience at Fort Conger, practically calm conditions were recorded at Lake Hazen for 24 hours after the wind at Alert reached a steady speed of $40 \mathrm{mph}$ and not until it had risen to $90 \mathrm{mph}$ on the coast did the wind reach 10 to $15 \mathrm{mph}$ at Lake Hazen.

The reasons for this great contrast remain essentially unknown. It was at first believed that the strong winds on the coast, particularly 


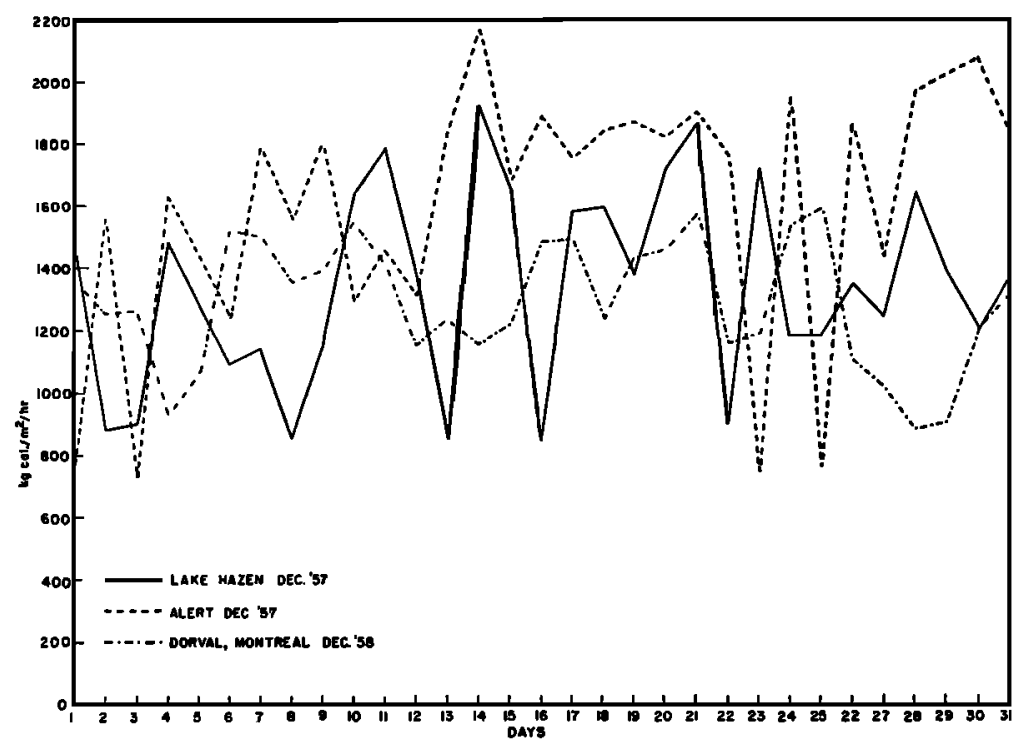

Fra. 1-Comparative values of windehill.

at Alert, might be local features peculiar to the area of the weather stations. An examination of synoptic maps, however, has shown that on most occasions the high winds were associated with strong pressure gradients and it is the Lake Hazen station that is anomalous. Wilson and Markham [1957] have in fact shown that the ratio of surface to gradient wind at Alert is relatively low. As the Lake Hazen station had neither pilot balloon nor rawinsonde equipment the height to which these calm conditions continue above the station is not known, but it is significant that snow lay apparently undisturbed on the slopes of "Mount McGill," behind the station, until it was blown off during the January gale. Therefore, fairly calm conditions must be normal up to at least 3000 feet above sea level (about $900 \mathrm{mb}$ ).

The combination of these two elements, temperature and wind, is important from the human aspect. There can be no doubt that, despite the very much colder temperatures, living conditions are very much more pleasant at the inland site than on the exposed and windswept coast near Alert. Figure 1 shows windchill values for December 1957 at Alert and Lake Hazen and, for comparison, for December 1958 at Montreal Airport. The monthly mean temperatures were, respectively, $-32^{\circ} \mathrm{F}$, $-48^{\circ} \mathrm{F}$, and $+11^{\circ} \mathrm{F}$. The values shown in the figure are the highest windchills at any of the 8 observations made each day. It is apparent that the very much lower temperatures at Lake Hazen are balanced by the lack of wind; the great fluctuations in the curve for that station represent the difference between days of absolute calm and those with light winds. The usual values throughout the winter were between 1200 and 1400 units, relatively low values.

Although living conditions at a small station are hence usually favorable, the same conditions of low temperatures and light winds present a handicap to a larger installation, especially one involving frequent aircraft movements, because of the liability to ice fog. Appleman [1953] investigated the conditions under which such fogs develop; Figure 2 summarizes his findings. It will be seen that at a station such as Lake Hazen, where very low temperatures are a practically constant feature during the winter, the presence of hydrocarbon nuclei from heating units or aircraft engines would cause condensation and persistent ice fogs. These would be made worse by the lack of sufficient wind to disperse them. The only aircraft to visit Lake Hazen during the winter of 1957-1958, a C-130A Hercules of the U. S. Air Force, caused an ice 


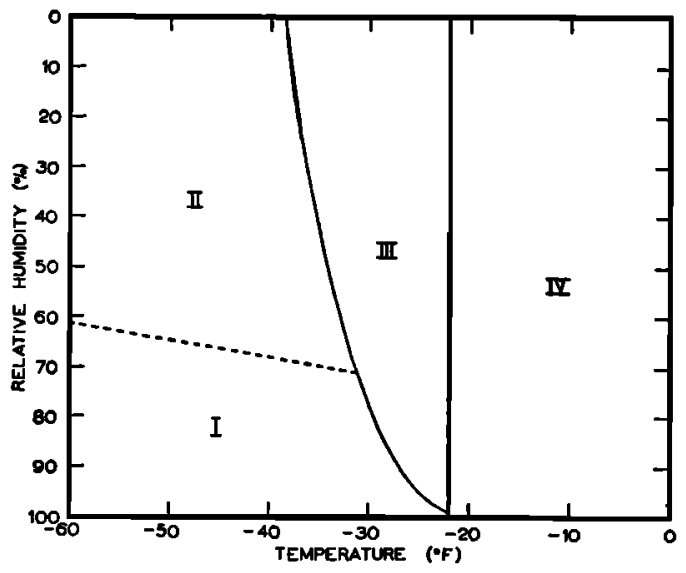

Fig. 2-Conditions necessary for the formation of ice fog (after Appleman).

I. Region of persistent ice fogs; atmosphere supersaturated with respect to ice.

II. Region of nonpersistent ice fogs; atmosphere subsaturated with respect to ice.

III. Region of no ice fog; combustion causes drying of atmosphere.

IV. Region of no ice fog; combustion causes drying of atmosphere; droplets will not freeze.

fog to develop on takeoff which did not clear for more than 4 hours.

Precipitation amounts at the three stations during the period are summarized in Table 2 . Alert clearly had a much greater snowfall, and in particular a much greater rainfall, than either Eureka or Lake Hazen. The differences between Eureka and Lake Hazen are not so great as at first appears. Most of the excess snowfall at Eureka occurred in 1 month, September 1957, and on 1 day, September 2, the amount was one-quarter of the total throughout the 11 months and 10 days considered.

In Table 2 the measurable precipitation is slightly less than 1 inch at Lake Hazen, whereas the total fall was probably about 1.5 inches. The difference is contained in the 'traces' of precipitation, 187 in all, which did not reach a measurable amount (greater than 0.005 inch water equivalent). These traces are to a large extent due to the Canadian practice of taking measurements every 6 hours, and it seems desirable that this interval should be considerably longer in the Arctic, as clearly a significant proportion of the total fall goes unrecorded.

During the summers of 1957 and 1958, a glacial-meteorological station was maintained on the Gilman Glacier, about 20 miles north of the Base Camp and 3400 feet above sea level. Sagar [1959] has drawn attention to the contrast between the two stations in the matter of summer precipitation. Totals between May 5 and August 10, 1958, were 1.42 inches on the glacier and 0.17 inch by the lake, of which snow accounted for 1.11 inches and 0.10 inch (water equivalents) respectively. A study of synoptic conditions in the periods when the major falls took place showed that the precipitation was of essentially orographic origin. Occasional fronts were present, approaching Ellesmere Island either from the west or the south, but they would have had little effect had it not been for the presence of the mountains. The other lowland stations, Alert and Eureka, show few similarities to the Gilman Glacier, and the high rainfall at Alert is a product of the low cloud and fog which are frequent along the north coast in summer.

A study of the months of December 1957 and January 1958 revealed several features of interest concerning the relation of events in the lower troposphere to surface weather in midwinter. In particular, it showed that the most

TABLe 2-Precipitation during 1957-1958

\begin{tabular}{lcccccc}
\hline Station & $\begin{array}{c}\text { Total, } \\
\text { in. }\end{array}$ & $\begin{array}{c}\text { Total days } \\
\text { trace or more }\end{array}$ & $\begin{array}{c}\text { Total days } \\
\text { more than trace }\end{array}$ & $\begin{array}{c}\text { (4) as percentage } \\
\text { of (3) }\end{array}$ & $\begin{array}{c}\text { Total } \\
\text { rain, in. }\end{array}$ & $\begin{array}{c}\text { (6) as percentage } \\
\text { of (2) }\end{array}$ \\
\hline (1) & $(2)$ & $(3)$ & $(4)$ & $(5)$ & $(6)$ & $(7)$ \\
\hline Lake Hazen & 0.98 & 134 & 39 & 29.1 & 0.07 & 7.1 \\
Eureka & 2.07 & 169 & 49 & 29.0 & 0.10 & 4.8 \\
Alert & 4.52 & 171 & 95 & 55.6 & 0.84 & 18.6 \\
\hline
\end{tabular}




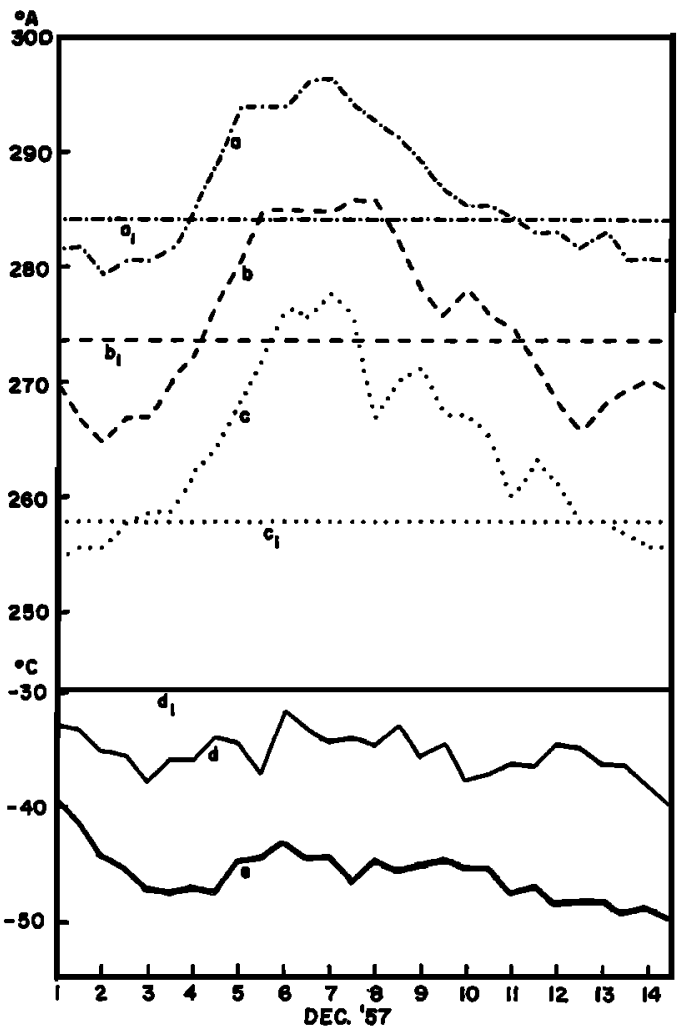

FIG. 3-Tropospheric warming in early December 1957. $a, b$, and $c$ are twice-daily values of potential temperature over Alert at 500, 700, and $850 \mathrm{mb}$, respectively; $d$ is the actual surface temperature; $a_{1}-d_{1}$ are mean December values, 1950 1953, for the various levels; $e$ is the actual surface temperature at Lake Hazen.

important requirements for a rise in temperature at the surface are light surface winds or the presence of a cloud cover. A surface wind will cause mixing of the cold air near the ground with the warmer air aloft, and a cloud cover, or falling snow, will raise the surface temperature by long-wave radiation. By contrast, a warm lower troposphere by itself has little effect. Figure 3 shows conditions at Alert and Lake Hazen during the first half of December 1957. The free air over Alert was considerably warmer than is usual in December [Canada, Department of Transport, 1955]. The cause of the warmth, however, was subsidence in a polar anticyclone, and, lacking either surface winds or clouds, surface temperatures at both Alert and Lake Hazen were unaffected.
Another result of this synoptic study was to show that a considerable proportion of the midwinter snowfall of northern Ellesmere Island appears to be derived from the area of the Norwegian Sea, the moist air reaching Alert and Lake Hazen by way of north Greenland. At this period it is the nearest source of extensive open water and appears to have a significant effect on winter weather, although in summer disturbances from Baffin Bay or the Pacific-Alaskan region are much more important.

Conclusion-This summary of the results of a year's record from Lake Hazen has shown that contrasts between the coast and interior of Ellesmere Island are greater than might have been expected. The combination of low temperatures and light winds, particularly in winter, has considerable importance for human occupation. It is apparent that a continued record, including some form of upper-wind measurements, would be of considerable value.

\section{References}

Appleman, $\mathrm{H}$., The cause and forecasting of ice fogs, Bull. Am. Meteorol. Soc., 34, 397-400, 1953.

Canada, Department of Transport, Meteorological Division, Climatological Summary, Alert, N.W. T, Canada, June 1950-December 195s, Toronto, $71 \mathrm{pp}$., 1955.

Great Britain, Parlamentary Papers, Journals and Proceedings of the Arctic Expedition 1876-76 under the Command of Capt. Sir George S. Nares, LVI, 1877.

Greelt, Adolphos Washington, Report on the Proceedings of the U.S. Expedition to Lady Franklin Bay, Grinnell Land, Govt. Printing Office, Washington, D. C., 2 vols., 1888.

МонN, H., Meteorology, 389 pp., in Norske Videnskaps-akad. Oslo, 'Report of the Second Norwegian Arctic Expedition in the Fram 18981902', Vol. I, Kristiania, 1907-1919.

SAaAR, R. B., Glacial-Meteorological Studies in North Ellesmere Island, 1958, M.Sc. thesis, McGill University, Montreal, 181 pp., 1959.

Thomas, Morley K., and T. L. Tirus, Abnormally mild temperatures in the Canadian Arctic during January 1958, Monthly Weather Rev., 86, 19-22, 1958.

Witson, H. P., and W. E. Markhan, A Study of Arctic Surface Winds, CIR-2923, TEC-251, Canada, Dept. of Transport, Meteorological Branch, 1957.

(Manuscript received July 13. 1959.) 